\title{
Enumeration and Identification of 4-Ethylphenol Producing Yeasts Recovered from the Wood of Wine Ageing Barriques after Different Sanitation Treatments
}

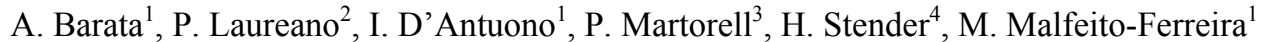 \\ A. Querol ${ }^{3} \&$ V. Loureiro ${ }^{1}$ \\ ${ }^{1}$ Univ Tecn Lisboa, Microbiology Laboratory, CBAA, ISA, Instituto Superior de Agronomia, Tapada da Ajuda, \\ Lisboa, Portugal \\ ${ }^{2}$ Departamento de Fitotecnia, Universidade de Évora, Évora, Portugal \\ 3 Departamento de Biotecnología, Instituto de Agroquímica y Tecnología de Alimentos (CSIC), Burjassot, \\ València, Spain \\ ${ }^{4}$ AdvanDx Inc., Concord, MA, USA \\ Correspondence: M. Malfeito-Ferreira, Laboratório de Microbiologia, Departamento de Botânica e Engenharia \\ Biológica, Instituto Superior de Agronomia, Lisboa 1349-017, Portugal. Tel: 351-213-653-448. E-mail: \\ mmalfeito@isa.utl.pt
}

Received: June 27, 2012 Accepted: December 15, 2012 Online Published: January 27, 2013

doi:10.5539/jfr.v2n1p140 URL: http://dx.doi.org/10.5539/jfr.v2n1p140

\begin{abstract}
Aims: This work was aimed at the evaluation of several sanitation procedures on the reduction of total microbial flora and of D. bruxellensis recovered from the inner layers of the barrique's wood.

Methods: A group of used oak barrels tainted by 4-ethylphenol and contaminated with D. bruxellensis were differently sanitized and, afterwards, were dismantled to analyse samples of shaves taken from wood surfaces at different depths. Microbial counts were obtained by the Most Probable Number Technique using broths of general purpose medium and of Dekkera/Brettanomyces differential medium (DBDM).

Results: The least inefficient treatment included barrique steaming at low pressure. Uncontaminated samples were only detected under this treatment and in the upper level $(0-2 \mathrm{~mm})$ of the staves. With this treatment complete destruction of the contaminating flora was not achieved in any level of stave side surfaces and in grooves. The presence of $D$. bruxellensis was detected in depths up to 6-8 $\mathrm{mm}$ in the wood corresponding to the maximum level of wine penetration.

Significance: this work demonstrated that even after current sanitation procedures barriques used in wine maturation pose a severe risk to wine stability due to the presence of D. bruxellensis.
\end{abstract}

Keywords: wooden barrels, disinfection, volatile phenols, Dekkera bruxellensis, Pichia guilliermondii

\section{Introduction}

The utilisation of wood barrels for wine ageing is widespread and is aimed at the improvement of wine quality. However, it also increases the risk of microbial spoilage because of the difficulty to sanitise properly the wood or to keep adequate levels of sulphur dioxide in wines. Wooden barrels are particularly known as a preferential ecological niche for yeasts of the genera Dekkera/Brettanomyces which are the agents of phenolic-odour taints described as "band-aid", "stable" and "horse sweat", due to the production of 4-ethylphenol and 4-ethylguaiacol (Chatonnet et al., 1995, 1997). Therefore, utmost care should be taken in barrel cleaning and disinfection. Chemical agents, mainly those with chlorine, are not suitable for wood treatment because of off-flavour release and so most common empirical sanitation procedures include hot water or steam utilisation followed, or not, by addition of sulphur dioxide to the barrels prior to wine filling. Even with thorough sanitation barrels always remain as a critical point in microbiological control (Guzzon et al., 2011). Recent reports have described the use of other sanitising agents like ozone (Marko et al., 2005), high-power ultrasonics (Schmid et al., 2011, Porter et al., 2011) and microwaves (González-Arenzana et al., 2013). However, these new strategies require the investment in specific equipments. Therefore, our work was directed to compare the effectiveness of sanitation 
procedures commonly used in wineries on the total microbial flora and on the yeasts able to produce high levels of 4-ethylphenol in the inner wood layers of ageing barrels.

\section{Material and Methods}

\subsection{Barrel Treatments and Sample Collection}

French oak barrels (250 1), with 4 year use, were selected to this study because of the detection of red wine with high levels of 4-ethylphenol and contaminated with Dekkera bruxellensis. Wine was from the 1996 vintage and analysed in 1999 giving $0.9949 \mathrm{~g} \mathrm{ml}^{-1}$ volumic mass, $12.55 \%(\mathrm{v} / \mathrm{v})$ ethanol, $16 \mathrm{mg} \mathrm{l}^{-1}$ free $\mathrm{SO}_{2}, 60 \mathrm{mg} \mathrm{l}^{-1}$ total $\mathrm{SO}_{2}, 5.29 \mathrm{~g} \mathrm{l}^{-1}$ total acidity in tartaric acid, $0.72 \mathrm{~g}^{-1}$ volatile acidity in acetic acid, $2.8 \mathrm{~g} \mathrm{l}^{-1}$ reducing sugars and $\mathrm{pH}$ 3.86. Average 4-ethylphenol level was $1.67 \mathrm{mg}^{-1}$ and $D$. bruxellensis counts ranged from 0.4 to $9.5 \times 10^{3}$ $\mathrm{CFU} \mathrm{m}{ }^{-1}$, determined previously according to Rodrigues et al. (2001). After emptying, each barrel was subjected to commonly used cellar practices: (A) blank, without treatment; (B) pre-rinsing with cold water, rinsing with hot water $\left(70^{\circ} \mathrm{C}\right)$ for 3 times and air-drying; (C) pre-rinsing with cold water, rinsing with hot water $\left(70^{\circ} \mathrm{C}\right)$, filling with sulphur dioxide solution (200 $\mathrm{mg}^{-1}$ ) acidified at $\mathrm{pH} 3.0$ and storage for one month; (D) pre-rinsing with cold water, filling with hot water $\left(90^{\circ} \mathrm{C}\right)$ up to $3 / 4$ of the volume, for $15 \mathrm{~min}$; (E) pre-rinsing with cold water, rinsing with hot water $\left(70^{\circ} \mathrm{C}\right)$, steaming under pressure $\left(0.5 \mathrm{kgf} \mathrm{cm}^{-2}\right)$ for $10 \mathrm{~min}$. Afterwards barrels were dismantled and from each one were selected different sampling points (Table 1). From each point were taken shaves with $2 \mathrm{~mm}$ thickness until the layer where no wine was observed, by means of a flame sterile chisel. The sampling areas were $50 \mathrm{~cm}^{2}$ for the internal surface of the staves, $15 \mathrm{~cm}^{2}$ for the side surface of the staves, 7.5 $\mathrm{cm}^{2}$ for the external surface of the stave groove and $20 \mathrm{~cm}^{2}$ in the river reed stalks. The staves were kept in sterile plastic bags until used.

Table 1. Sampling points in the wooden barrels

\begin{tabular}{lll}
\hline Reference & Sampling points & Sampling depth \\
\hline I & Internal surface of the stave located in opposite side of bung hole & $0-2,2-4,4-6,6-8 \mathrm{~mm}$ \\
II & Side surface of the stave located in opposite side of bung hole & $0-2,2-4 \mathrm{~mm}$ \\
III & Groove of the stave located in the opposite side of the bung hole & External, internal \\
IV & Internal surface of the stave of the bung hole & $0-2,2-4,4-6,6-8 \mathrm{~mm}$ \\
V & Side surface of the stave of the bung hole & $0-2,2-4 \mathrm{~mm}$ \\
VI & Groove of the stave of the bung hole & External, internal \\
VII & Internal surface of the bung hole & $0-2,2-4,4-6 \mathrm{~mm}$ \\
VIII & Internal surface of the stave adjacent to the bung hole (I) & $0-2,2-4,4-6,6-8 \mathrm{~mm}$ \\
IX & Side surface of the stave adjacent to the bung hole (I) & $0-2,2-4$ mm \\
X & Groove of the stave adjacent to the bung hole (I) & External, internal \\
XI & Internal surface of the stave adjacent to the bung hole (II) & $0-2,2-4,4-6,6-8 \mathrm{~mm}$ \\
XII & Side surface of the stave adjacent to the bung hole (II) & $0-2,2-4 \mathrm{~mm}$ \\
XIII & Groove of the stave adjacent to the bung hole (II) & External, internal \\
XIV & Internal surface of the side stave (I) & $0-2,2-4,4-6,6-8 \mathrm{~mm}$ \\
XV & Side surface of the side stave (I) & $0-2,2-4 \mathrm{~mm}$ \\
XVI & Groove of the side stave (I) & External, internal \\
XVII & Internal surface of the side stave (II) & $0-2,2-4,4-6,6-8 \mathrm{~mm}$ \\
XVIII & Side surface of the side stave (II) & $0-2,2-4 \mathrm{~mm}$ \\
XIX & Groove of the side stave (II) & External, internal \\
XX & Internal surface of the side stave of the head & $0-2,2-4,4-6,6-8 \mathrm{~mm}$ \\
XXI & Side surface of the side stave of the head & $0-2,2-4 \mathrm{~mm}$ \\
XXII & Groove of the side stave of the head & External, internal \\
XXIII & Internal surface of the central stave of the head & $0-2,2-4,4-6,6-8 \mathrm{~mm}$ \\
XXIV & Side surface of the central stave of the head & $0-2,2-4 \mathrm{~mm}$ \\
XXV & Groove of the central stave of the head & External, internal \\
XXVI & River reed stalks of the staves of the head & Shredded pieces \\
\hline
\end{tabular}




\subsection{Microbial Counts}

Samples of wood shaves were inoculated in $100 \mathrm{ml}$ of $30 \mathrm{~g} \mathrm{l}^{-1}$ Tryptic Soy broth (Merck, Darmstadt, Germany), $20 \mathrm{~g} \mathrm{l}^{-1}$ Yeast extract (Merck) and $1 \mathrm{ml} / 1$ of Tween 80 (Merck), with orbital shaking $(125 \mathrm{rpm}$ ) for $24 \mathrm{~h}$. These solutions were serially diluted $\left(10^{-1}\right.$ to $\left.10^{-5}\right)$ in Ringer solution (Oxoid) and inoculated in series of 3 tubes for each dilution according to Most Probable Number (MPN) technique (Vaz-Oliveira et al., 1995).

Total microbial counts were obtained using the medium GYP $\left(10 \mathrm{~g} \mathrm{l}^{-1}\right.$ glucose, $5 \mathrm{~g}^{-1}$ yeast extract, $10 \mathrm{~g} \mathrm{l}^{-1}$ peptone and $20 \mathrm{~g} \mathrm{l}^{-1}$ agar, $\mathrm{pH} 6.0$ ) incubated for 5 days at $25^{\circ} \mathrm{C}$. Positive results were determined by visual observation of medium turbidity.

Yeasts of the genera Dekkera/Brettanomyces sp. were quantified using the medium DBDM (Rodrigues et al., 2001). Positive results were recorded after turbidity observation and phenolic smell detection as described by Rodrigues et al. (2001). Samples from the most diluted positive tubes were streaked onto DBDM plates. Growth characteristics in DBDM medium were evaluated on the basis of medium acidification, colony morphology and detection of phenolic taint by smelling, after incubation at $25^{\circ} \mathrm{C}$ for up to 14 days (Rodrigues et al., 2001). Typical colonies were further purified to confirm the presence of $D$. bruxellensis by PNA hybridization and to evaluate 4-ethylphenol production, as described below. The strains were maintained in GYP medium $\left(20 \mathrm{~g} \mathrm{l}^{-1}\right.$ glucose (Merck), $5 \mathrm{~g} \mathrm{l}^{-1}$ yeast extract (Difco Laboratories, Detroit, USA), $10 \mathrm{~g} \mathrm{l}^{-1}$ peptone (Difco) and $20 \mathrm{~g} \mathrm{l}^{-1}$ agar, $\mathrm{pH}$ 6.0) added of $5 \mathrm{~g}^{-1}$ of calcium carbonate (Merck), at $4^{\circ} \mathrm{C}$.

\subsection{Production of Volatile Phenols}

A loopful of fresh culture (24-48 h) was suspended in Ringer solution and used to inoculate the YNB medium (Difco) $\left(6.7 \mathrm{~g} \mathrm{l}^{-1}\right)$ supplemented with glucose $\left(20 \mathrm{~g} \mathrm{l}^{-1}\right)$ and $p$-coumaric acid $\left(100 \mathrm{mg} \mathrm{l}^{-1}\right)$ (Sigma Chemical Co., St. Louis, USA), adjusted to $\mathrm{pH} 5.4$ and filter sterilized. Volatile phenols were measured according to a protocol described by Rodrigues et al. (2001). Briefly, the volatile phenols were extracted by ether-hexan from a $50 \mathrm{ml}$ sample with $\mathrm{pH}$ adjusted to 8 with $\mathrm{NaOH}$. The volatile phenols were separated by collecting the organic phase of the mixture. The quantitation was achieved by gas chromatography using a DB-Wax capillary column (J \& W Scientific, Folsom, California, USA).

\subsection{PNA FISH Hybridization}

Colonies were smeared onto microscope slides (Erie Scientific, Portsmouth, NH), heat fixed and analyzed by fluorescence in situ hybridization (FISH) using peptide nucleic acid PNA probes targeting 26S rRNA of $D$. bruxellensis (CGGTCTCCAGCGATT) as described by Stender et al. (2001). Microscopic examinations were performed using a fluorescence microscope (Dialux 20, Leica Microsystems, Cambridge, United Kingdom) and $D$. bruxellensis was identified as bright fluorescent yeast cells.

\subsection{PCR Amplification and 5.8S-ITS Restriction Analysis}

Isolates obtained from samples of wood, which were not identified as D. bruxellensis by PNA probe, were identified by restriction analysis of 5.8S-ITS region according to Esteve-Zarzoso et al. (1999). PCR amplification was carried out in an Eppendorf Thermal Cycler using DyNAzyme ${ }^{\mathrm{TM}}$ II DNA Polymerase (Finnzymes OY, Espoo, Finland). PCR products were digested with CfoI, HaeIII and HinfI (Roche Molecular Biochemicals, Manheim, Germany), and fragments separated on 3\% agarose gel.

\section{Results}

\subsection{Effect of Sanitation Treatments}

The enumeration of total microbial flora after different sanitation treatments of the barrels is shown in Table 2 . In order to be statistically compared results higher than $7.15 \log _{10}$ MPN counts assumed the value 7.15 , and to the absence of counts in $10^{-1}$ dilution was given the value 0 . In this way, statistical analysis (ANOVA, at 0.05 level) of the mean of the $\log _{10}$ MPN counts obtained with the treatment A (blank) and the mean obtained with the other treatments, showed that: i) B treatment yielded higher counts than A; ii) the differences between A and $\mathrm{C}$ or D treatments were not statistically different; iii) E treated barriques yielded significantly lower counts than the blank A. In addition, most of the lowest counts (56 samples in a total of 68) were obtained with $E$ treatment (Table 2) and this was the single treatment to yield null counts in the initial suspension ( $10^{-1}$ dilution) of the oak shaves. These sampling points without measurable contamination were all in the $0-2 \mathrm{~mm}$ layer of the internal surface of the staves. However, even with E treatment there were spots of inefficient sanitation. These were the grooves between body staves and head stave, particularly in the external surface where E treatment produced the lowest counts only in 2 of the 8 sampling points. In this case, $\mathrm{C}$ treatment was the most efficient by showing the 
lowest counts in 4 out of the 8 sampling points. The side surface of the staves was also a point of inefficient sanitation, for which not even the most efficient treatment $\mathrm{E}$ was able to reduce microbial counts substantially.

Table 2. Enumeration of yeasts ( $\log 10$ MPN cm${ }^{-2}$ of wood shave) recovered from different levels of the wood of barrels after sanitation (treatments A to E)

\begin{tabular}{|c|c|c|c|c|c|c|}
\hline Origin & Sampling depth (mm) & $\mathbf{A}$ & B & $\mathrm{C}$ & D & $\mathbf{E}$ \\
\hline \multirow[t]{4}{*}{$\mathrm{I}$} & $0-2$ & 2.95 & 4.95 & 2.45 & 2.25 & 0* \\
\hline & $2-4$ & 2.15 & 5.34 & 2.15 & 3.70 & 0.70 \\
\hline & $4-6$ & 1.48 & 1.90 & 1.90 & 0.70 & 1.26 \\
\hline & $6-8$ & 1.26 & 1.70 & 1.70 & 1.95 & 1.26 \\
\hline \multirow[t]{2}{*}{ II } & $0-2$ & 3.22 & 4.22 & 3.86 & 3.70 & 2.47 \\
\hline & $2-4$ & 3.80 & 3.47 & 3.80 & 3.22 & 3.22 \\
\hline \multirow[t]{2}{*}{ III } & External & 4.52 & 5.52 & 5.00 & 4.78 & 4.73 \\
\hline & Internal & 5.78 & 5.78 & 4.52 & 4.52 & 3.52 \\
\hline \multirow[t]{4}{*}{ IV } & $0-2$ & 2.28 & 2.28 & 3.78 & 3.18 & $\mathbf{0}$ \\
\hline & $2-4$ & $\mathrm{Nd}$ & 3.95 & 3.51 & 3.70 & 1.70 \\
\hline & $4-6$ & 2.70 & 2.70 & 2.70 & 3.17 & 2.70 \\
\hline & $6-8$ & 2.48 & 2.48 & 2.70 & 2.70 & 2.18 \\
\hline \multirow[t]{2}{*}{ V } & $0-2$ & 3.00 & 5.87 & 4.48 & 4.48 & 1.78 \\
\hline & $2-4$ & 4.87 & 4.48 & 4.87 & 4.70 & 3.22 \\
\hline \multirow[t]{2}{*}{ VI } & External & $>7.15$ & $>7.15$ & 5.78 & 5.78 & 4.78 \\
\hline & Internal & 3.97 & $>7.15$ & 4.08 & 5.00 & 3.52 \\
\hline \multirow[t]{3}{*}{ VII } & $0-2$ & 3.52 & 3.52 & 4.78 & 3.00 & 0 \\
\hline & $2-4$ & 5.52 & 3.52 & 4.00 & 4.78 & 2.78 \\
\hline & $4-6$ & 4.52 & 5.78 & 4.52 & 4.73 & 3.73 \\
\hline \multirow[t]{4}{*}{ VIII } & $0-2$ & $>7.15$ & $>7.15$ & $>7.15$ & 3.18 & 0.70 \\
\hline & $2-4$ & 0.90 & 3.95 & 3.08 & 3.90 & 2.95 \\
\hline & $4-6$ & 1.95 & 3.95 & 3.18 & 3.95 & 3.70 \\
\hline & $6-8$ & 3.48 & 3.48 & 3.48 & 3.70 & 2.70 \\
\hline \multirow[t]{2}{*}{ IX } & $0-2$ & 3.70 & 3.48 & 5.48 & 3.48 & 2.48 \\
\hline & $2-4$ & 4.87 & $>7.15$ & 5.48 & 3.70 & 3.22 \\
\hline \multirow[t]{2}{*}{$\mathrm{X}$} & External & 3.52 & 5.78 & 4.52 & 5.78 & 5.78 \\
\hline & Internal & 4.43 & 4.43 & 2.78 & 4.00 & 3.52 \\
\hline \multirow[t]{4}{*}{ XI } & $0-2$ & 4.95 & 4.95 & 4.95 & 2.70 & $\mathbf{0}$ \\
\hline & $2-4$ & 3.70 & 3.70 & 5.18 & 3.18 & 2.18 \\
\hline & $4-6$ & 1.26 & 1.26 & $>7.15$ & 3.34 & 3.18 \\
\hline & $6-8$ & 0.70 & 0.70 & 4.70 & 3.18 & 2.90 \\
\hline \multirow[t]{2}{*}{ XII } & $0-2$ & 2.80 & 4.80 & 4.12 & 3.70 & 1.78 \\
\hline & $2-4$ & 4.70 & 4.48 & 4.48 & 3.87 & 3.70 \\
\hline \multirow[t]{2}{*}{ XIII } & External & 5.30 & 5.30 & 6.17 & 5.30 & 4.30 \\
\hline & Internal & 5.30 & $>7.15$ & 3.73 & 4.78 & 4.00 \\
\hline
\end{tabular}




\begin{tabular}{|c|c|c|c|c|c|c|}
\hline \multirow[t]{4}{*}{ XIV } & $0-2$ & 2.28 & 5.28 & 2.28 & 1.95 & $\mathbf{0}$ \\
\hline & $2-4$ & 4.95 & 3.95 & 4.70 & 2.70 & 0.70 \\
\hline & $4-6$ & 3.34 & 3.18 & 3.78 & 3.18 & 2.90 \\
\hline & $6-8$ & 2.90 & 2.90 & 3.18 & 2.90 & 2.18 \\
\hline \multirow[t]{2}{*}{$\mathrm{XV}$} & $0-2$ & 2.22 & 3.22 & 4.30 & 3.48 & 1.78 \\
\hline & $2-4$ & 3.43 & 2.48 & 3.70 & 3.70 & 3.22 \\
\hline \multirow[t]{2}{*}{ XVI } & External & 4.78 & 5.78 & 4.78 & 5.17 & 5.78 \\
\hline & Internal & 5.78 & 4.52 & 5.30 & 4.00 & 3.30 \\
\hline \multirow[t]{4}{*}{ XVII } & $0-2$ & 4.70 & 4.95 & 4.18 & 2.95 & $\mathbf{0}$ \\
\hline & $2-4$ & 3.60 & 3.95 & 3.26 & 1.95 & 1.28 \\
\hline & $4-6$ & 2.78 & 2.70 & 2.78 & 3.18 & 2.70 \\
\hline & $6-8$ & 3.34 & 3.34 & 5.28 & 3.18 & 2.18 \\
\hline \multirow[t]{2}{*}{ XVIII } & $0-2$ & 5.48 & 5.48 & 5.87 & 4.22 & 3.22 \\
\hline & $2-4$ & 4.80 & 4.80 & 5.87 & 4.80 & 4.42 \\
\hline \multirow[t]{2}{*}{ XIX } & External & 5.10 & 5.78 & 5.00 & 6.00 & 5.78 \\
\hline & Internal & 4.67 & $>7.15$ & $>7.15$ & 5.52 & 4.52 \\
\hline \multirow[t]{4}{*}{$\mathrm{XX}$} & $0-2$ & 2.70 & 2.70 & 3.60 & 2.95 & 1.95 \\
\hline & $2-4$ & 3.85 & 3.85 & 3.85 & 3.85 & 1.95 \\
\hline & $4-6$ & 2.70 & 2.70 & 2.70 & 3.18 & 3.18 \\
\hline & $6-8$ & 2.90 & 2.90 & 4.70 & 3.70 & 2.70 \\
\hline \multirow[t]{2}{*}{ XXI } & $0-2$ & $>7.15$ & $>7.15$ & 5.48 & 4.70 & 3.70 \\
\hline & $2-4$ & 5.22 & 5.22 & 3.78 & 4.48 & 4.22 \\
\hline \multirow[t]{2}{*}{ XXII } & External & 5.78 & 6.18 & 5.30 & 6.18 & 5.78 \\
\hline & Internal & 5.78 & $>7.15$ & $>7.15$ & 5.78 & 4.52 \\
\hline \multirow[t]{4}{*}{ XXIII } & $0-2$ & $>7.15$ & $>7.15$ & 4.28 & 3.18 & $\mathbf{0}$ \\
\hline & $2-4$ & 3.95 & 3.95 & 3.70 & 3.70 & 2.70 \\
\hline & $4-6$ & 3.60 & 4.70 & 3.95 & 4.18 & 3.34 \\
\hline & $6-8$ & 3.95 & 3.95 & 3.51 & 3.95 & 2.70 \\
\hline \multirow[t]{2}{*}{ XXIV } & $0-2$ & 4.22 & $>7.15$ & 4.22 & 5.87 & 3.22 \\
\hline & $2-4$ & 5.87 & 5.87 & 4.80 & 5.48 & 3.48 \\
\hline \multirow[t]{2}{*}{ XXV } & External & $>7.15$ & $>7.15$ & 3.10 & $>7.15$ & $>7.15$ \\
\hline & Internal & 4.52 & 5.78 & $>7.15$ & 4.00 & 4.00 \\
\hline \multirow[t]{2}{*}{ XXVI } & Pieces & $>7.15$ & 5.10 & 5.10 & 4.57 & 4.35 \\
\hline & $\begin{array}{l}\text { Mean } \dagger \\
\text { deviation }\end{array}$ & $4.03 \pm 1.61$ & $4.58 \pm 1.65$ & $4.32 \pm 1.29$ & $3.93 \pm 2.85$ & $2.85 \pm 1.59$ \\
\hline
\end{tabular}

*The lowest counts in each row of table are written in bold.

$\dagger$ The means of the log counts were estimated assuming the value 7.15 for counts higher than 7.15 , and the value 0 for the absence of counts in $10^{-1}$ dilution. 


\subsection{Quantification and Typing of 4-Ethylphenol Producing Yeasts}

The enumeration of yeasts with positive results in the DBDM medium is shown in Tables 3 and 4. It was possible to evidence the presence of 4-ethylphenol producing yeasts in the wood up to the layers of 6-8 $\mathrm{mm}$ depth. In most sampling points these yeasts only represent a small proportion of the total contaminating flora.

The tests with $D$. bruxellensis specific PNA probe showed that almost all strains with positive growth response in DBDM hybridised with this probe (Table 3). These strains should then be assigned to the species $D$. bruxellensis.

Table 3. Enumeration of strains isolated at different levels in the wood of barriques and with positive hybridization with the PNA probe specific for $D$. bruxellensis

\begin{tabular}{|c|c|c|c|c|c|}
\hline Strain & Treatment & Origin & $\begin{array}{l}\text { Isolation depth } \\
(\mathrm{mm})\end{array}$ & $\begin{array}{l}\text { MPN counts* } \\
\text { (DBDM/GYP) }\end{array}$ & $\begin{array}{l}\text { Relative predominance } \\
(\%)\end{array}$ \\
\hline 400 & $\mathrm{~A}$ & I & $0-2$ & $50 / 900$ & 5.6 \\
\hline 402 & A & I & $4-6$ & $5 / 18$ & 27.8 \\
\hline 405 & A & III & External & $6000 / 33333$ & 18.0 \\
\hline 411 & A & VII & $2-4$ & $120 / 33333$ & 0.4 \\
\hline 416 & A & IX & $2-4$ & $500 / 90000$ & 0.6 \\
\hline 418 & A & XII & $0-2$ & $167 / 300000$ & 0.06 \\
\hline 419 & A & $\mathrm{XX}$ & $4-6$ & $50 / 500$ & 10.0 \\
\hline 423 & A & XXV & Internal & $1267 / 33333$ & 3.8 \\
\hline 531 & A & VII & $4-6$ & $333 / 33333$ & 1.0 \\
\hline 532 & A & $\mathrm{X}$ & External & $1267 / 3333$ & 38.0 \\
\hline 533 & A & XIX & External & $3333 / 126667$ & 2.6 \\
\hline 534 & A & XXIII & $4-6$ & $<1 / 4000$ & $<0.02$ \\
\hline 535 & $\mathrm{C}$ & VIII & $0-2$ & $500 />140000000$ & $<0.004$ \\
\hline 536 & $\mathrm{C}$ & XII & $0-2$ & $1667 / 13333$ & 12.5 \\
\hline 537 & $\mathrm{C}$ & XVI & Internal & $14800 / 200000$ & 7.4 \\
\hline 538 & $\mathrm{C}$ & $\mathrm{XX}$ & $6-8$ & $50 / 50000$ & 0.1 \\
\hline 539 & B & I & $2-4$ & $90 / 220000$ & 0.04 \\
\hline 540 & B & II & $0-2$ & $167 / 733333$ & 0.02 \\
\hline 541 & B & VII & $4-6$ & $600 / 600000$ & 0.1 \\
\hline 542 & B & VIII & $4-6$ & $90 / 9000$ & 0.1 \\
\hline 543 & $\mathrm{D}$ & IV & $6-8$ & $50 / 500$ & 10.0 \\
\hline 544 & $\mathrm{D}$ & VII & $4-6$ & $333 / 53333$ & 0.6 \\
\hline 545 & $\mathrm{E}$ & $\mathrm{V}$ & $2-4$ & $17 / 1667$ & 1.0 \\
\hline 546 & $\mathrm{E}$ & XIII & External & $120 / 20000$ & 0.6 \\
\hline 547 & $\mathrm{E}$ & XVI & External & $120 / 600000$ & 0.02 \\
\hline 548 & $\mathrm{E}$ & XXV & External & $600 />140000000$ & $<0.0004$ \\
\hline 549 & $\mathrm{E}$ & VII & $4-6$ & $120 / 5333$ & 2.3 \\
\hline
\end{tabular}

* Ratio between the MPN counts in DBDM and GYP broths.

The strains with positive growth response in DBDM and not hybridising with the specific probe are listed in Table 4. The strains growing in DBDM but without releasing phenolic smell (negative response) are listed in Table 5. 
The 4-ethylphenol production in synthetic medium was evaluated for all strains recovered from the DBDM broth. All D. bruxellensis strains produced high amounts of 4-ethylphenol (results not shown). Among the 3 strains not hybridising with the PNA specific probe the amount of 4-ethylphenol produced in synthetic medium was high only for the strain $430 \mathrm{~b}$ (Table 4). In figure 1 are shown representative results of growth and 4-ethylphenol production by one strain of $D$. bruxellensis and by strain $430 \mathrm{~b}$, showing similar maximum levels of 4-ethylphenol attained and much higher growth rates for $P$. guilliermondii.

As expected all strains in table 5 yielded rather low conversion rates of p-coumaric acid into 4-ethylphenol, producing less than $1.2 \mathrm{mg} \mathrm{l}^{-1}$ of 4-ethylphenol.

Table 4. Enumeration of strains isolated at different levels in the wood of barriques with negative hybridization with the PNA probe specific for D. bruxellensis and growing in DBDM medium releasing phenolic smell

\begin{tabular}{lllllll}
\hline Strain & Treatment & Origin & $\begin{array}{l}\text { Isolation depth } \\
(\mathbf{m m})\end{array}$ & $\begin{array}{l}\text { MPN counts } \\
\text { (DBDM/GYP) }\end{array}$ & $\begin{array}{l}\text { Relative } \\
\text { predominance }(\%)\end{array}$ & 4-EP* \\
\hline 417 & A & XVI & External & $1267 / 60000$ & 2.1 & 1.2 \\
420 & A & XXII & External & $600 / 600000$ & 0.1 & 0.7 \\
$430 \mathrm{~b}$ & A & I & $2-4$ & $1 / 140$ & 0.7 & 51.0 \\
\hline
\end{tabular}

* Maximum production of 4-ethylphenol $\left(\mathrm{mg} \mathrm{l}^{-1}\right)$ in synthetic medium added of $100 \mathrm{mg} \mathrm{l}^{-1}$ of $p$-coumaric acid (mean of 2 independent experiments).

Table 5. Enumeration of strains isolated at different levels in the wood of barriques with negative hybridization with the PNA probe specific for D. bruxellensis and growing in DBDM medium without releasing phenolic smell

\begin{tabular}{|c|c|c|c|c|c|c|c|}
\hline Strain & $\begin{array}{l}\text { Colony } \\
\text { colour }\end{array}$ & Treatment & Origin & $\begin{array}{l}\text { Isolation } \\
\text { depth }(\mathbf{m m})\end{array}$ & $\begin{array}{l}\text { MPN counts } \\
(\mathrm{DBDM} / \mathrm{GYP})\end{array}$ & $\begin{array}{l}\text { Relative } \\
\text { predominance }(\%)\end{array}$ & 4-EP* \\
\hline 403 & Pink & $\mathrm{A}$ & I & $6-8$ & $5 / 18$ & 27.8 & $-\dagger$ \\
\hline 404 & Pink-orange & A & II & $0-2$ & $1667 / 1667$ & 100.0 & 0.2 \\
\hline 406 & Yellow grey & B & IV & $0-2$ & $5 / 190$ & 2.6 & 1.2 \\
\hline 407 & Yellow grey & A & IV & $2-4$ & $5 /-$ & - & 0.9 \\
\hline 408 & $\begin{array}{l}\text { Yellow } \\
\text { white }\end{array}$ & A & IV & $4-6$ & $90 / 500$ & 1.8 & 0.9 \\
\hline 409 & Yellow grey & A & $\mathrm{V}$ & $0-2$ & $633 / 1000$ & 63.3 & 0.7 \\
\hline 410 & Olive green & A & VI & Internal & $-/ 9333$ & - & 0.6 \\
\hline 412 & Olive green & A & VIII & $4-6$ & $50 / 90$ & 55.6 & 0.3 \\
\hline 413 & $\begin{array}{l}\text { Yellow } \\
\text { white }\end{array}$ & A & IX & $2-4$ & $300 / 733333$ & 0.04 & 0.6 \\
\hline 414 & Yellow grey & A & XI & $6-8$ & $18 / 50$ & 36.0 & 1.0 \\
\hline 415 & Olive green & $\mathrm{A}$ & XIII & Internal & $600 / 200000$ & 0.03 & 0.1 \\
\hline 421 & $\begin{array}{l}\text { Yellow } \\
\text { white }\end{array}$ & $\mathrm{A}$ & XIII & $6-8$ & $8 / 9000$ & 0.09 & 0.7 \\
\hline 422 & Yellow & A & XXIV & $2-4$ & $167 / 733333$ & 0.02 & 0.1 \\
\hline
\end{tabular}

* Maximum production of 4-ethylphenol (mg l-1) in synthetic medium added of $100 \mathrm{mg}^{-1}$ of $p$-coumaric acid.

$\uparrow$ Not determined. 


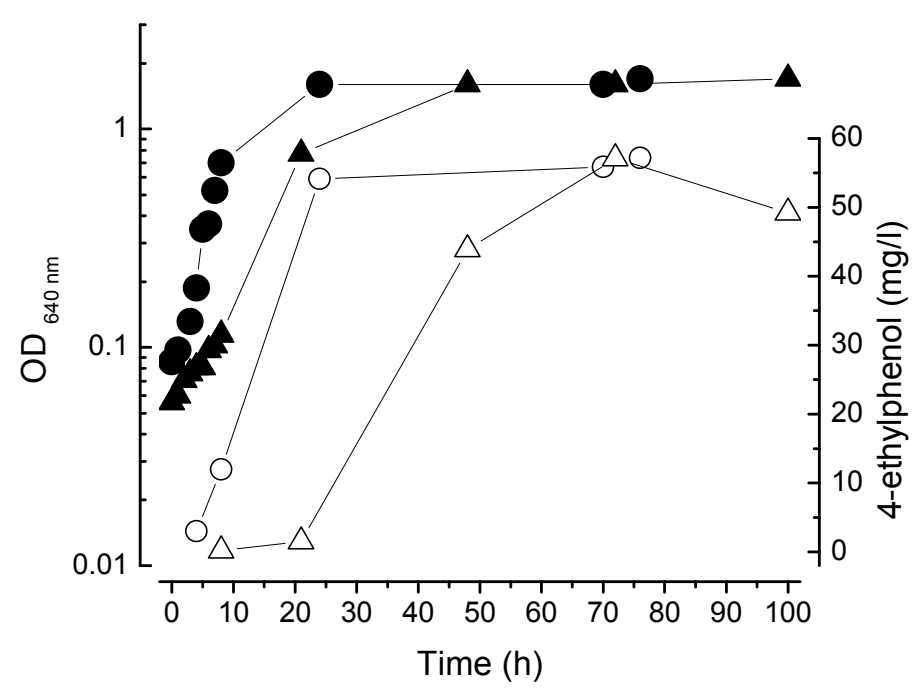

Figure 1. Growth (filled symbols) and production of 4-ethylphenol (open symbols) by strains $430 \mathrm{~b}$ (circles) and D. bruxellensis strain 535 (triangles). Maximum growth rates $\left(\mathrm{h}^{-1}\right)$ were 0.37 for strain $430 \mathrm{~b}$ and 0.11 for strain 535

\subsection{Strain Identification by RFLPs of 5.8S-ITS}

The yeast species able to grow on DBDM medium and not hybridising with the PNA probe were identified by RFLP of 5.8S-ITS region. The identifications are listed in table 6 showing that the most common species was $P$. guillermondii. Other strains were assigned to Candida parapsilopsis, Rhodotorula mucilaginosa and Torulaspora globosa. Both P. guillermondii and Candida parapsilopsis released phenolic smell in DBDM medium but only strain $430 \mathrm{~b}$ of $P$. guilliermondii yielded high amounts of 4-ethylphenol in synthetic medium (see Tables 4 and 5).

Table 6. Strain identification by RFLPs of the 5.8-ITS region of isolates from different levels in the wood of barriques

\begin{tabular}{|c|c|c|c|c|c|}
\hline \multirow[t]{2}{*}{ Strain } & \multirow[t]{2}{*}{$\overline{\text { AP* }^{*}(\mathbf{b p})}$} & \multicolumn{3}{|c|}{ Restriction enzymes } & \multirow[t]{2}{*}{ Species } \\
\hline & & CfoI & HaeIII & HinfI & \\
\hline 417 & 550 & $310+240$ & $420+130$ & $280+270$ & Candida parapsilopsis \\
\hline 420 & 625 & $300+265+60$ & $400+115+90$ & $320+300$ & Pichia guillermondii \\
\hline $430 \mathrm{~b}$ & 625 & $300+265+60$ & $400+115+90$ & $320+300$ & Pichia guillermondii \\
\hline 403 & 620 & $300+220+100$ & $410+210$ & $350+220+50$ & Rhodotorula mucilaginosa \\
\hline 404 & 620 & $300+220+100$ & $410+210$ & $350+220+50$ & Rhodotorula mucilaginosa \\
\hline 406 & 550 & $310+240$ & $420+130$ & $280+270$ & Candida parapsilopsis \\
\hline 407 & 625 & $300+265+60$ & $400+115+90$ & $320+300$ & Pichia guillermondii \\
\hline 408 & 625 & $300+265+60$ & $400+115+90$ & $320+300$ & Pichia guillermondii \\
\hline 409 & 625 & $300+265+60$ & $400+115+90$ & $320+300$ & Pichia guillermondii \\
\hline 410 & 625 & $300+265+60$ & $400+115+90$ & $320+300$ & Pichia guillermondii \\
\hline 412 & 625 & $300+265+60$ & $400+115+90$ & $320+300$ & Pichia guillermondii \\
\hline 413 & 625 & $300+265+60$ & $400+115+90$ & $320+300$ & Pichia guillermondii \\
\hline 414 & 625 & $300+265+60$ & $400+115+90$ & $320+300$ & Pichia guillermondii \\
\hline 415 & 650 & $300+300+50$ & $420+150+80$ & $325+325$ & Torulaspora globosa \\
\hline 421 & 625 & $300+265+60$ & $400+115+90$ & $320+300$ & Pichia guillermondii \\
\hline 422 & 625 & $300+265+60$ & $400+115+90$ & $320+300$ & Pichia guillermondii \\
\hline
\end{tabular}

\footnotetext{
* Amplification product.
} 


\section{Discussion}

The comparison of the microbial counts among the different barrels must take into account that each treatments was done in independent barrels and that each barrel may have harboured different initial microbial loads. In addition, for a single barrel, microbial distribution in the wood is not uniform. Having in mind these considerations, the results obtained with the different sanitation procedures suggest that none was able to reduce significantly the contaminating microflora. However, the less inefficient treatment was that using steam under low pressure. The loss of efficiency was observed with increasing the depth of sampling in the wood and in points not reached by steam (external surfaces of groves and side surfaces of staves). In this case only dismantling and further steaming could have reduced the contamination levels. It is surprising that the most common procedure in Portuguese cellars - B treatment - showed results statistically similar to those of barrel without treatment. This observation can be explained by higher initial counts in the B treated barrel.

Most of D. bruxellensis strains were isolated in the untreated barrel. However, this species was isolated after any of the sanitation procedures carried out. The presence of D. bruxellensis was evidenced up to the 6-8 $\mathrm{mm}$ depth layer, corresponding to the maximum depth of wine penetration. In most sampling points this species represented a small proportion of the contaminating flora, as already observed in bulk wines (Rodrigues et al., 2001). Concerning the most efficient $\mathrm{E}$ treatment, the presence of $D$. bruxellensis was evidenced in the external surface of grooves, side surface of staves $(2-4 \mathrm{~mm})$ and in the bunghole $(4-6 \mathrm{~mm})$. Therefore, these points should be regarded as critical during sanitation. Contaminated barrels should be treated after dismantling or discarded to minimise or avoid, respectively, the risk of wine contamination. Assuming an average internal area of $2.1 \mathrm{~m}^{2}$ for a 2501 barrel (Schahinger \& Rankine, 1992) and an average of 100 cells cm of $^{-2}$. bruxellensis per each of the 4 layers of staves, one reaches the initial inoculum level of $33 \mathrm{cells} / \mathrm{ml}$ of a hypothetical sterile wine introduced into a sanitised barrel. The fact that 6 cells ml ${ }^{-1}$ of $D$. bruxellensis were reported as being able to produce $1 \mathrm{mg} \mathrm{l}^{-1}$ of 4-ethylphenol during a period of 4.5 month barrel maturation (Chatonnet et al., 1993) leads to the conclusion that the most effective treatment does not eliminate the risk of contamination. According to González-Arenzana et al. (2013) also reported the isolation of Brettanomyces spp. from $8 \mathrm{~mm}$ depth after microwave treatment. Thus, steam treatment should be regarded as an additional procedure in the prevention of $D$. bruxellensis activity and not as the key to its elimination.

The species isolated from the wood other than D. bruxellensis, were Pichia guillermondii, Candida parapsilopsis, Rhodotorula mucilaginosa and Torulaspora globosa. From this group only one strain of $P$. guillermondii showed the ability to produce high levels of 4-ethylphenol as already observed by us (Dias et al., 2003). It remains to be seen if this ability also occurs in wines. If so, strains of this species should be regarded as well as spoilage agents. Otherwise, all mentioned species should be regarded as innocent contaminants concerning spoilage by 4-ethylphenol production.

\section{Conclusion}

From this study arises the conclusion that the recovery of used barrels is a difficult task to achieve. This operation must include the removal of all wood layers soaked with wine. Other treatments with ozone, microwave or ultrasonics may have similar efficiency. However, it is likely that the limiting factor of any treatment is the prevention of contact between the sanitising agent and the microbial cells which occurs when microorganisms are imbedded in deep wood layers.

\section{Acknowledgements}

The authors gratefully acknowledge the technical assistance of Carla Silva. The work was sponsored by national research project AGRO 96 and FCT foundation by project PTDC/AGR-ALI/113565/2009.

\section{References}

Chatonnet, P., Boidron, J., \& Dubourdieu, D. (1993). Influence des conditions d'élevage et de sulfitage des vins rouges en barriques sur le teneur en ácide acétique et en ethyl-phenols. J. Int. Sc. Vigne Vin, 27, 277-298.

Chatonnet, P., Dubourdieu, D., \& Boidron, J. N. (1995). The influence of Brettanomyces/Dekkera sp. yeasts and lactic acid bacteria on the ethylphenol content of red wines. Am. J. Enol. Vitic., 46, 463-468.

Chatonnet, P., Viala, C., \& Dubourdieu, D. (1997). Influence of polyphenolic components of red wines on the microbial synthesis of volatile phenols. Am. J. Enol. Vitic., 48, 443-448.

Dias, L., Dias, S., Sancho, T., Stender, H., Querol, A., Malfeito-Ferreira, M., \& Loureiro, V. (2003). Identification of yeasts originated from wine related environments and capable of producing 4-ethylphenol. Food Microbiol., 20, 567-574. http://dx.doi.org/10.1016/S0740-0020(02)00152-1 
Esteve-Zarzoso, B., Belloch, C., Uruburu, F., \& Querol, A. (1999). Identification of Yeasts by RFLP Analysis of the 5.8S rRNA Gene and the Two Ribosomal Internal Transcribed Spacers. Int. J. Syst. Bacteriol., 49, 329-337. http://dx.doi.org/10.1099/00207713-49-1-329

González-Arenzana, L., Santamaría, P., López, R., Garijo, P., Gutièrrez, A., Garde-Cerdán, T., \& López-Alfaro, I. (2013). Microwave technology as a new tool to improve microbiological control of oak barrels: a preliminary study. Food Control, 30, 536-539. http://dx.doi.org/10.1016/j.foodcont.2012.08.008

Marko, S., Domedy, E., Fugelsang, K., Dormedy, D., Gump, B., \& Wample, R. (2005). Analysis of oak volatiles by gas-chromatography-mass spectrometry after ozone santization. Am. J. Enol. Vitic., 56, 1, 46-51.

Porter, G., Lewis, A., Barnes, M., \& Williams, R. (2011). Evaluation of high power ultrasound porous cleaning efficacy in American oak wine barrels using X-ray tomography. Innov. Food Sc. Emerg. Technol., 12, 509-514.

Rodrigues, N., Gonçalves, G., Malfeito-Ferreira, M., \& Loureiro, V. (2001). Development and use of a differential medium to detect yeasts of the genera Dekkera/Brettanomyces. Int. J. Food Microbiol., 90, 588-599.

Schahinger, G., \& Rankine, B. (1992). Cooperage for winemakers. Adelaide: Ryan Publications. http://dx.doi.org/10.5344/ajev.2011.11014

Schmid, F., Grbin, P., Yap, A., \& Jiranel, V. (2011). Relative efficiency of high-pressure hot water and high-power ultrasonics for wine oak barrel sanitization. Am. J. nol. Vitic., 64, 4, 519-526.

Stender, H., Kurtzman, C., Hyldig-Nielsen, J., Sorensen, D., Broomer, A., Oliveira, K., ... Coull, J. (2001). Identification of Dekkera bruxellensis (Brettanomyces) from wine by fluorescence in situ hybridization using peptide nucleic acid probes. Appl. Environ. Microbiol., 67, 938-941. http://dx.doi.org/10.1128/AEM.67.2.938-941.2001

Vaz-Oliveira, M., Barros, P., \& Loureiro, V. (1995). Analyse microbiologique du vin. Tecnhiques des tubes multiples pour l'enumeration de micro-microorganisms dans les vins. Feuilles Verts O. I. V., 987, Paris. 